\title{
IN SEARCH OF THE ETHOS OF THE BRAZILIAN CONSTITUTION ${ }^{1}$
}

\section{EM BUSCA DO ETHOS DA CONSTITUIÇÃO DO BRASIL}

Recebimento: 12 fev. 2020

Aceitação: 9 fev. 2021

Melina Girardi Fachin

Doutora em Direito

Afiliação institucional: Universidade Federal do Paraná - UFPR - (Curitiba, PR, Brasil) Lattes iD: http://lattes.cnpq.br/1368334568714375

Email: melinafachin@gmail.com

Rodrigo Luís Kanayama

Doutor em Direito

Afiliação institucional: Universidade Federal do Paraná - UFPR - (Curitiba, PR, Brasil)

Lattes iD: http://lattes.cnpq.br/6130548557084828

Email: rodrigo@kanayama.adv.br

Como citar este artigo / How to cite this article (informe a data atual de acesso / inform the current date of access):

FACHIN, Melina Girardi; KANAYAMA, Rodrigo Luís. In search of the Ethos of the Brazilian Constitution. Revista da Faculdade de Direito UFPR, Curitiba, v. 66, n. 1, p. 95-116, jan./abr. 2021. ISSN 2236-7284. Disponível em: https://revistas.ufpr.br/direito/article/view/71687. Acesso em: $30 \quad$ abr. $2021 . \quad$ DOI: http://dx.doi.org/10.5380/rfdufpr.v66i1.71687.

\section{ABSTRACT}

This article intends to identify the Ethos of the Federal Constitution of Brazil, if any. The search will be made in direct dialogue with the work of Alexander Tsesis, Constitutional Ethos (2017). From this perspective ethos represents core maxim of constitutionalism, namely: protection of individual rights for the common good. Despite the idea of ethos has been firmly constructed under the US Constitution reality, that is vastly different from the Brazilian one, so its existence is uncertain in the Brazilian Constitution. In this identification process, a historical perspective is brought up from the Brazilian constitutional texts, tracing a parallel between the Brazilian promulgated constitutions, to then deal specifically with the 1988 Constitution. In this sense, many comparisons are made between the Brazilian and American constitutions, conducting a parallel with the aforementioned work of Professor Alexander Tsesis. Based on a bibliographical research, upon a comparative methodology, the goal is to explore if the Brazilian constitutionalism, because of its historical contexts and complexities, has an ethos, and if so, to understand how susceptible to changes and threats it is.

This study is the result of the discussions held at UFPR, Brazil, during the second semester of 2018, with master's and doctoral students. From the recent work of Professor Alexander Tsesis - Constitutional Ethos: Liberal Equality for the Common Good (2017) -, long and productive debates were promoted on the Ethos of the United States Constitution and then on the existence of the Ethos of the Brazilian Constitution. 


\section{KEYWORDS}

Constitutional Ethos. Brazilian Constitution. United States Constitution.

\section{RESUMO}

Este artigo procura identificar, se existente, o Ethos da Constituição Federal do Brasil. A busca será feita em diálogo direto com a obra de Alexander Tsesis, Constitucional Ethos (2017). Nessa perspectiva, o ethos representa a máxima central do constitucionalismo, a saber: a proteção dos direitos individuais para o bem comum. Apesar de a ideia de ethos ter sido firmemente construída sob a realidade da Constituição dos Estados Unidos, esta é muito diferente da brasileira e, portanto, sua existência é incerta na Constituição do Brasil. Nesse processo de identificação, é trazida uma perspectiva histórica a partir dos textos constitucionais brasileiros, traçando-se um paralelo entre as constituições brasileiras promulgadas, para então se tratar especificamente da Constituição de 1988. Nesse sentido, muitas comparações são feitas entre as constituições brasileira e americana, conduzindo-se um paralelo com a mencionada obra do professor Alexander Tsesis. Com base em pesquisa bibliográfica, com metodologia comparada, o objetivo é explorar se o constitucionalismo brasileiro, em função de seus contextos e complexidades históricas, possui um ethos e, em caso afirmativo, compreender o quão suscetível a mudanças e ameaças ele é.

\section{PALAVRAS-CHAVE}

Ethos constitucional. Constituição do Brasil. Constituição dos Estados Unidos.

\section{INTRODUCTION}

Brazil has a rich constitutional history - not only because of the number of constitutions enacted (there are seven, plus amendments and revisions), but especially because of the political facts that precede each one. There were many Brazilian Constitutions in the history of Brazil'², a total of eight (1824, 1891, 1934, 1937, 1946, 1967, 1969³ 1988), the last seven in the Republican period: four promulgated and democratic (1891, 1934, 1946, 1988), four imposed (1824, 1937, 1967, 1969).

Regarding this distinction between the texts promulgated and granted, it is important to consider the lesson of Viana (1927, p. 13, our translation), for whom:

of the democratic constructions raised in our country - from the Imperial Constitution of [18] 24 to the Republican Constitution of [18] 91, passing by the Process Code of [18] 32 and the Additional Act of [18] 34 - none of them really succeeded in subsisting in their purity: all of them were condemned to failure, but look for the cause of this failure - and it will be seen that it is precisely that none of these constructions was based on mortar bases with the clay of our living reality - of our social reality - of our national reality.

2 It is not the aim of the present reflection to trace the history of Brazilian constitutionalism, this is why the article explores only the constitutional texts.

3 By its extension and materiality, despite the form of constitutional amendment, for the functions and senses that this presentation takes as Constitution, considering the amendment to the constitution of 1969 to be a true constitution. 
It is not the purpose of this section to trace the historical panorama of Brazilian constitutionalism, but it is necessary to return to the constitutional frameworks in the search of an eventual ethos of Brazilian Constitution. Bearing this in mind is important for, on the one hand, avoiding a linear apprehension of history, to have its sense of place (HESPANHA, 1997, p. 15) and, on the other hand, to reveal the heavy cultural conditioning ${ }^{4}$ of these structures.

From Brazilian constitutional path, one can conclude that the Brazilian democracy has been intermittent and, since the last dictatorial period (1964-1985), young. The intermittencies of the democratic model and its instability drink much of its transitioned origin from the civilian military regime. In this sense, the Constitution appears not just as a rupture, but as a process of change:

The legend of the Geisel government was, as we know, "slow, gradual and secure” political distension. This procedure should be dragged far enough away that it cannot be interpreted as an involution of the "Revolution", serving as a pretext for the open challenge of the extreme right, military and civil. It should also be gradual, that is, progressive and limited, as it could not pave the way for an opposition offensive that would lead, for example, to a democratic rupture (QUARTIM DE MORAES, 1982, p. 766-767). And it should be controlled by the President himself, since the two previous tasks required strict supervision of both the political movements of the military right and the parliamentary left. Only in this way is the meaning of Geisel's pendular strategy reconstituted, now on the right (cassations), now on the left (elections) (CODATO, 2005, p. 94, our translation).

With the formal end of the dictatorship in 1985, Brazil had a new Constitution debated by elected representatives and promulgated on October 5, 1988 its current Constitution. The adoption of the new Constitution occurs within a context of democratic transition agreed upon:

The "democratic consolidation" took place within a peculiar institutional framework. The scenario resulting from the new Constitution combined presidentialism as the form of government, federalism as the formula for the relationship between the central state and subnational units (MAINWARING, 1997), the political coalition as the formula for governability (ABRANCHES, 1988), all of this supported on a fragmented party system (NICOLAU, 1996), little institutionalized and too regionalized (ABRUCIO 1998). This institutional combination - or, for some, this institutional deformation - ultimately led to the transition process to the following point: an electoral democracy, an imperial executive and a congressional regime that acts either as a collaborator, or as a saboteur of the initiatives of the President, central actor of the political system. (CODATO, 2005, p. 84-85, our translation).

In confrontation with the authoritarian regime of 1964 that the movement in 1987-1988 for a Constituent Assembly was formed and it is the legacy of the dictatorial experience that weighs most heavily on the democratic institutions now in force. Despite its origin in an amendment to the

4 Regarding this, Paolo Grossi (2006, p. 1, our translation) maintains that "the historian, who perceives the line and its meaning, is, by its own vocation, a relativizer and a demystifier, and is therefore the irreplaceable companion that restores each legal norm, to each institute its real measure in the relative terrain of history". 
authoritarian regime's Constitution ${ }^{5}$, the Constituent Assembly process represented a political rupture, and was guided by the centrality of the people, committing itself with the core values of democracy. In this sense, Barbosa (2012, p. 148, our translation) highlights:

The pronouncement of the sovereign people would not be incarnated by the unison of the authoritarian voice, endorsed by the bacharelic varnish, but by an authentic polyphony, the meaning of which can only be learned in movement, in its own making. This is the original note that gives the 1988 Constitution a truly revolutionary character.

The result - the text of 1988 Brazilian Constitution - was a provisional pact between the countless political forces in dispute in transition regime. This resulted in a very broad and wide constitutional text, on topics that would not refer exclusively to constitutional matters, in addition to a large number of subjects that would depend on subsequent regulation and the constant change of the text due to the political needs of the moment. This is why is an extensive Constitution, which text encompasses the interests and needs of a plural society. It is, in fact, an intervening constitution, which seeks to solve some deep problems in the Brazilian society, aiming to promote fundamental rights and guarantees, social rights, regulated and contained the powers of the Republic, and ensured citizenship (BONAVIDES; ANDRADE, 1989).

About the birth of 1988's Constitution:

The 1988 Constitution represented, in relation to the previous ones, an undeniable advance in terms of political and social rights. But, elaborated in a period of democratic euphoria, during which there was an illusion that an ideal society could be created through the simple mechanism of inscribing in the Magna Carta everything that seemed just and desirable, it has a marked utopian character. A small dose of utopia is necessary, as it points out objectives that are expected to be achieved. But its excess creates unfulfillable expectations that can only lead to widespread frustrations. (GOLDEMBERG; DURHAM, 1993, p. 167, our translation).

The constitutional text itself already contained the germ of many of the changes it underwent afterwards. Furthermore, a Constitution is not born a Constitution, but becomes. As Derrida (2002, p. 47) states, reinforcing the idea of living constitution, the Constitution is a contextualized statement endowed with a performative sense. That is why it is wrong to speak of the Constitution of 1988, because, in fact, it is the contextualized reading of this Constitutional project that is in force today. For better or worse, it is Strauss’ idea of living constitution (JARDIM, 2012, p. 162).

\footnotetext{
5 “[...] once transmitted by constitutional amendment, the summons of the Constituent Assembly would be nothing more than the manifestation of a power of reform, not of an original power. However, calling a legal rule a 'constitutional amendment' does not make it a constitutional amendment against its own normative structure. An elementary distinction, such as that constructed by doctrine between law in a formal sense and law in a material sense, shows that judging a rule by the way it is titled can lead to misunderstandings.” (BARBOSA, 2012, p. 192, our translation).
} 
It is in this troubled scenario that this work will seek to verify the existence of a Brazilian constitutional ethos. This search will be made in direct dialogue with the work of Alexander Tsesis (2017), Constitutional Ethos.

It is certain that the Brazilian Constitution is very distant to the Constitution of the United States. The US Constitution is stable (at least in time and text) and long-lived, has undergone few modifications, corresponding as an example of synthetic Constitution. The United States Constitution of 1787 is the first written Constitution of the Western history. For its elaboration, there were two focal points: the powers of the federal government and the individual rights and guarantees.

One can extract, as Professor Alexander Tsesis says in his book, an Ethos of the Constitution. The ethos relies on a liberal but and at the same time equal society, "tolerant to the diverse groups composing it” (TSESIS, 2017, p. 28). It is not a “textual creation”, but a "principle of justice that the collective group, commonly referred to as 'the people', recognizes to have higher normative status than any contemporary majority” (TSESIS, 2017, p. 85). The ethos allows people to achieve their goals as individuals of a plural society, while active members of the same society.

Despite the idea of ethos has been firmly constructed under the US Constitution, its existence is uncertain in the Brazilian Constitution, which is young and has received 99 amendments in the last 30 years, emerging doubts over its healthy longevity. Actually, there is no reflection, still, on the Ethos of Constitutionalism. Based on a bibliographical research, upon a comparative methodology, this work, inspired by the reading of the above-mentioned work of Professor Tsesis, search for the Ethos of the Brazilian Constitutionalism - if any.

\section{APPROACHES AND DISTANCES}

Although the Brazilian and US constitutional models are very different, there are similarities that allow to make the research that is intended herein. Likewise, there are many and fundamental differences - the stability of US democracy and constitution longevity are only a small part of the distances between the constitutional systems. Anyway, the goal is to promote a comparative study 
focused on the ethos of the Constitutions since the existence of the ethos is independent of the written constitution - it is connected to the people.

The Constitutional model of 1891, which inaugurated the Republic in Brazil, took great inspiration from the United States constitutionalism, which prevailed over the European model ${ }^{6}$. One of the oldest national claims, federalism was the basic discussion in the Constituent Assembly especially, as it could not be different, regarding the division of powers among the Union and federative States ${ }^{7}$.

On the other hand, the fact is that the national experience of the Empire period imposed differences in relation to the US model ${ }^{8}$. There was a whole system of material law here, originating from the imperial system, which was approved by the Constitution of 1891 - in the condition of federal rules (Civil, Commercial and Criminal Law). The same is true regarding the constitutional provisions dealing with the Ministers of State - in the USA, Ministers are only mentioned at a glance; in the 1981 Brazilian Constitution, there is a whole chapter about the subject (for instance, Chapter IV - Ministers of State).

Thus, the first Brazilian Republican Constitution of February 24, 1891 simultaneously broke the unitary form of state (making it federative); the monarchical form of government (making it republican) and the representative regime (from parliamentary to presidential). Despite democratic disruptions during the twentieth century, those structures remained throughout the history of the Brazilian constitutionalism, including in the model of 1988, currently in force.

As the object of the present article is not the analysis of each of the constitutional documents, it aims in the 1988 Constitution. It is not ignored, on the other hand, that the Constitution is the result of the historical journey that has reached the present day, but that due to the methodological approach it will not be the object of this article ${ }^{9}$.

6 "Within the Commission of the five or the 'historic', three projects appeared which were compressed into one, sent in June to the Provisional Government. It was inspired by the express provisions of the constitutions of the USA, Argentina, and Switzerland, and others would not be adequate since almost all Republicans desired a federalist presidential republic, except the positivists desirous of the 'scientific dictatorship' with the executive's absolute preponderance over the legislative.” (BALEEIRO, 2012, p. 25, our translation).

7 Each federation is unique. The definition of powers shared between the Union and the States is the result of a political game. In the words of José Arthur Castillo de Macedo (2018, p. 148, our translation), "it is evident that powers [of the Union and of the States] are defined by the power's relationships created in the constitutional assembly, but the powers define important points in the posterior political game”.

8 "The monarchical federalists of the end of the Empire, Rui Barbosa and Joaquim Nabuco, were more for political reasons than for conviction. None of them was a staunch federalist. But they were convinced that the federalist demand had become irresistible and that the federation would be made, with or without the Empire. They admitted the possibility of a federal monarchy, a hypothesis flatly denied by the Republicans, who made the need for the federation one more argument for the overthrow of the Empire.” (CARVALHO, 2011, p. 141-157, our translation).

9 To find out more, see: BONAVIDES; ANDRADE, 1989. 


\section{THE CURRENT CONSTITUTIONAL PARADIGM}

The current Constitution is the milestone of the Brazil’s democratic transition, still in progress, and which has allowed the emergence of the protection of the human being in the contemporary legal order of the country. About this matter, Chueiri and Camara (2015, p. 284-285, our translation) state:

[...] it is only through understanding that the legal field was fundamental to the dictatorial organization (as well as the repression mechanisms that used violence) that we can map, at present, authoritarian legal practices. [...] The resumption of authoritarian historical time serves to make explicit that the Constitution is in dispute, a dispute between the memory of the Constitution's weakness and the forgetfulness forged by the speech of the winners.

Redemocratization called for the (re)construction and strengthening of democracy in order to overcome the authoritarian legacy and build the possibilities for the future. The human rights help in this democratic path, since they are at the same time a consequence and instrument of the exercising of the right to political-democratic participation required and demanded by transitional justice ${ }^{10}$.

As a relatively rigid model, at least in theory ${ }^{11}$, Brazilian Constitution has a specific and complex procedure to carry out those changes, requiring qualified majorities for its approval, which is much more difficult than the one for ordinary legislation ${ }^{12}$.

There are, in addition, circumstantial limits that refer to abnormal circumstances, when the Constitution cannot be amended, such as the state of emergency (in case of war, for example) or federal intervention.

Finally, there is still a barrier to the Parliament deliberation in certain subjects. These are the so-called unamendable or petrified clauses. Considering the substantive content of these provisions, Article 60 , $\S 4$, provides that a proposal of amendment aiming to abolish the federative form of the State; the direct, secret, universal and periodic vote; the separation of powers; and individual rights and guarantees will not be subject to deliberation.

It should be noted that the eternity clauses do not prevent any and all changes to the rules that make up the list of material limits. Denaturation of the basic option of the original constituent is

10 "As to the indivisibility of human rights, it should be emphasized that the 1988 Constitution is the first constitution that integrates social and economic rights into the list of fundamental rights, which in the previous Constitutions were pulverized in the chapter relevant to the economic and social order.” (PIOVESAN, 2008, p. 717, our translation).

11 "In theory" since Brazilian Constitution of 1988 was amended 108 times (up to 2020).

12 “Article 60. [...] Paragraph 4. No proposal of amendment shall be considered which is aimed at abolishing: I - the federative form of State; II - the direct, secret, universal and periodic vote; III - the separation of the Government Powers; IV - individual rights and guarantees.” (BRASIL, 1988, our translation). 
prohibited, which is not necessarily an impediment to reviewing the constitutional discipline of such clause. About these clauses, Branco (2017, our translation) teaches:

\begin{abstract}
The petrified clauses play a decisive role in maintaining the identity, in time and before institutions, of the sovereign will of the people, which expresses itself as the holder of the original constituent power. The normative strength of the Constitution depends on the population's and public authorities' adherence and loyalty to it. A Constitution that does not preserve its essential structure and that is deformed at each effervescence of each fleeting political moment, certainly that will have additional difficulty to impose itself as an element of firmness and stability for the attainment of the higher ends that inspired it. Taking petrified clauses seriously is a prerequisite for taking a consistent constitutional system seriously.
\end{abstract}

All this rigidity and formality, restraining Parliament's amending power, are justified in order to protect the hard-fought agreements embodied in the Constitution against the dangerous effect of opportunistic majorities. Such constraints are projected into the future in order to avoid contingent constitutional changes: allowing the adjustment of the Constitutional text as a living constitution, but at the same time, granting the necessary deference of the constitutional fundamental choices, are the targets of the legislative process of amendment.

Given this scenario that disembogues in 1988, it must be questioned whether it is possible to think of a common ethos of Brazilian constitution. For such purpose, it is imperative to evaluate what is being sought, that is, to locate the meaning of ethos.

\title{
3 ETHOS
}

In his work Tsesis appropriates the ethos idea of the classical antiquity as a set of fundamental customs and habits to think of it as something characteristic of North American constitutional tradition.

There seems to be a consensus in the United States that the Constitution is the supreme law of the land, but there is much disagreement as to what exactly this means. This indisputable truth is called into question in the search for constitutional ethos and its meaning, not only for North American constitutional history, but also for everyday issues in the constitutional debate. In its work Alexander Tsesis investigates into the fundamental principles of the constitutional principle, meaning and interpretation to pin the Constitutional Ethos for the North American constitutionalism.

Alexander Tsesis brings the following statement, which is the foundation of his argument: Government must pursue happiness, individual rights, equality, dignity for the common good. Government must act for people to achieve their goals. The Constitutional "Maxim” (axiom) is the normative public duty, which requires the government to protect individual liberties, with a balance 
between public and private interests. It is the overarching end of government, which defines "limits on power and holds the obligation to act for the public benefit” (TSESIS, 2017, p. 2).

In Tsesis point of view, the government exists only to provide means for people to achieve satisfaction by protecting the individual rights and liberties recognized by the Constitution. According to Alexander Tsesis, "the US Constitution is a repository of ancient and modern values needed to resolve normative and pragmatic concerns of private and public concerns” (TSESIS, 2017, p. 6).

The ethos is not the written text of the Constitution, but "Put in general terms, the constitutional ethos is a principle that empowers individuals to flourish by pursuing their unique life quests while also maintaining coercive standards for government to advance policies likely to achieve collective goods” (TSESIS, 2017, p. 85). Therefore, as the mentioned author states the Ethos of the United States Constitution is not as hard as a stone, since it must cover the whole of a plural society.

Stability in a plural society comes from the Declaration of Independence and the US Constitution, respecting the different views about happiness. In this sense Alexander Tsesis also points out that "the Preamble to the Constitution and the Declaration of Independence jointly define the national ethos of US constitutionalism” (TSESIS, 2017, p. 160).

It is the Preamble of the Declaration of Independence that establishes the idea and purposefulness of the constitutional project, as it yields an insight about the merits of fully integrating them into the way one think about the Constitution. The main goal is to expand the domain of constitutional understanding considering the Declaration of Independence and the Preamble as sources of constitutional meaning, that is, in the end, to grant individual rights to enable society to pursue the common good.

Tsesis's central thesis is based on the idea that even the laws enacted by popular majorities do not have authority, unless they are in accordance with the core maxim of constitutionalism, its ethos, namely: protection of individual rights for the common good. This principle of constitutional governance synthesizes the protection of individual rights derives from the Declaration of Independence and the Preamble, precedes the Constitution itself. Tsesis demonstrates that ethos is mandatory for all three branches of government and legitimates the exercise of power at all levels.

In sum it is to protect individual rights and achieve the common good of the society that, in the view of Alexander Tsesis work, the spirit of the Constitution was built and should be always considered in its reading. 


\section{IS THERE AN ETHOS IN BRAZILIAN CONSTITUTIONALISM?}

Because there is no single Brazilian Constitution, it is difficult or even impossible to establish a stable and perennial ethos.

The Constitution is not a result of the Big Bang, as if not even time existed before it. On the contrary, and very much today, after two centuries of constitutional history, the power to create a Constitution is a power actually exercised in a certain and specific historical circumstance, which brings with it the civilizational advances of those people who, at that time, put it into practice.

The Constitution is the legal way by which a politically organized society expresses its autonomy. "A constitution is always the translation of a society's political equilibrium into fundamental rules.” (PRADO JR., 1993, p. 48, our translation).

The Brazilian constitutional history is quite complex in this sense, either by the formal succession of eight constitutional models, or by the political facts that influenced it. That said, with all this plurality, is there an ethos in Brazilian constitutionalism?

Of all the Constitutions, only four can be considered democratic: 1891, 1934, 1946, 1988. This definition is open to debate because in Brazil, with the alternation between authoritarian and democratic regimes, and the profound institutionalization and legalization of the authoritarian periods ${ }^{13}$, the existence of repressive practices is also noted in the free regimes as an "authoritarian rubble” (FERNANDES, 1987, p. 9, our translation).

In the same sense, Barbosa (2012, p. 20, our translation) states:

[...] the law does not represent for authoritarian regimes just a "magic solution" to garner support or, at least, to oppose opposition. In order for it to function plausibly as a reserve of political authority, there must be, first of all, conditions to separate right and arbitrary, to distinguish between the current rules and the political will that governs. Without a minimum of respect for the "rules of the game", the use of politics to the law becomes innocuous. In the same way that political power keeps its potential for coercion "quartered", but ready for use, the law must also remain present as a source of justice.

The paper will focus on the democratic constitutional texts because the proper notion of constitutionalism has been attached to democracy since its modern origins. The only objective of this retrospective is to check if there is the permanence of an underlying spirit that - as in the model defended by Tsesis - precedes the Constitution (the Declaration of Independence and the Preamble, in the case of the work), and conforms it. However, considering the constituent moment as a rupture - although transitioned in the Brazilian 1987’s Assembly, as stated above - this historical rescue is done as an investigation of the ethos in the current Brazilian constitution, if any.

\footnotetext{
13 “The most brazen dictatorship loves laws.” (VENTURA, 1988, p. 161, our translation).
} 
By tracing back history from Brazilian democratic constitutional texts, one cannot find, according to Alexander Tsesis's theory, a common Brazilian constitutional ethos among these Constitutions.

The Constitution of 1891 was a result of a top-down rupture. The passage from the Empire to the Republic led to the production of a new Constitution, quite inspired by the Constitution of the United States. The period called Old Republic (República Velha) by the Brazilians had begun. This movement, profoundly inspired by U.S. constitutionalism, created the Brazilian institutional design that persists to this day.

These are some of the characteristics of its permanence or influence on time: it established the Republic (article 1) marked by elections (instrument of representation), periodicity (fidelity to the mandate and alternation in power), responsibility (guarantee of the suitability of representation) and harmonious separation of State powers and reciprocal control; it established Federalism as a "perpetual and indissoluble union of the former provinces in the United States of Brazil” (article 1); it instituted Presidentialism and the figure of the president "as elective head of the Nation" (Article 41); it established a list of rights and guarantees concerning freedom, individual security and property; it dissociated the church from the state, banning "official religions" and structured the powers.

The collapse of this model had much of consequence of the North American financial crisis of 1929 and Brazil was heavily affected. A series of events (refusal of congressional recognition to the Paraíba and part of Minas Gerais congressmen, assassination of João Pessoa, downfall of the government in Argentina, etc.) led to the revolution that started on October 3, 1930.

The Revolution of 1930 broke out in Brazil - in fact it was a coup against President-elect Julio Prestes, who went into exile. Getúlio Vargas took over the transitional government, revoked the Constitution of 1891 and the period called New Republic (República Nova) began.

In 1932, a movement against Getúlio Vargas government was launched: The Constitutionalist Revolution of São Paulo fought for a new Constitution. The Constitution of 1934 was the result of another institutional rupture and was short-lived - which in practice produced little or no result.

The Constitution of 1934 was discussed and voted on in a period when the foundations of traditional democracy were seriously shaken by: the crisis of individual liberty advocated by the Liberal State; the increasing prestige of the state as a dictatorial political entity (Nazi-fascist tones); the collapse caused by World War I, etc. Nevertheless, the 1934 Constitution is a democratic document that incorporates the novelties of the after-war constitutions. Its inspiring basis was the German Constitution of 1919 and the Spanish Constitution of 1931. As an influx of Nazi-fascist 
authoritarian movements prior to the Second World War, the 1934 Constitution succumbed to Getúlio Vargas's New State Regime in 1937. A dictatorial era began, in which what happened was not only the installation of a corporativist order of fascist inspiration. Arbitrariness was the mark of the antidemocratic order in which the President of the Republic was the "supreme authority of the State".

Trying to reestablish democracy again, the Constitution of 1946 was enacted, committed to the democratic ideal of the rule of law, and based on international new commitments with the rule of law and human rights. The compromise of the liberal state with social ideology marks the constitutional text that, despite the efforts, failed to pacify Brazilian democracy for a long time and another rupture arose in 1964 with the civil-military coup.

The 1946 Constitution lasted until the next institutional rupture, with the military coup of 1964 (originating the non-democratic Constitutions of 1967 and 1969). For more than 20 years (1964 to 1985), the Brazilians faced blatant disrespect for individual rights by the government, with torture, arbitrary arrests/detentions and murders.

After more than two decades of military dictatorship, formal democracy was re-established. The so called "lead years", one of the most violent and repressive periods in Brazilian history. Many opposites of the regime were indicted in an investigation under the National Security Law and hundreds of others were officially recognized years later as missing politicians. Censuring, arresting, torturing and killing was the modus operandi of such times ${ }^{14}$.

Another institutional breakdown, which required a new Constitution: the 1988 Constitution. At 30 years of age, it is still young and still faces difficult tests (it had been changed almost 100 times but is still alive). In line with this argument, Barbosa (2012, p. 252, our translation) continues:

\begin{abstract}
The history of constitutional changes under the 1988 Constitution is not the history of the development and preservation of that unprecedented foundational practice that emerged almost unexpectedly during the work of the National Constituent Assembly. For the reformist discourse, it is about the need to correct an error, a deviation. Correcting the excesses of a constitution that enshrines too many rights, that regulates too much and makes the government's task too complicated. A Constitution that needs, in Nelson Jobim's less delicate expression, a "liposuction”.
\end{abstract}

The democratic Constitutions in Brazil arose as a consequence of institutional fractures. The Empire to the Republic, from the Old Republic to the Estado Novo (New State), from the Estado Novo to the Third Republic, from this to the military dictatorship and, finally, to democracy. In the light of that conclusion, one cannot affirm the existence of an ethos underpinned in the Brazilian

14 For more, see: GASPARI, 2002. 
democratic Constitutions. Not, at least, as immanent in the Brazilian constitutional order, that is, not as a common spirit among the democratic Constitutions, as the will of the "people”.

\section{IS THERE AN ETHOS IN THE CURRENT BRAZILIAN CONSTITUTION?}

The focus here is on the Constitution of 1988, with its important defense of fundamental rights and guarantees, of individual rights and of the common good. Current constitutional protection is therefore the fruit and the reason for the transition insofar as it focuses on the preservation and promotion of rights, especially for vulnerable and disadvantaged groups. This democratic enlargement also corroborates the inclusion and empowerment of human rights, traditionally left behind by the hegemonic political agenda, which, in turn, is the key to democratic consolidation and the just transition to democracy.

In light of that, one can repeat the question: Is there an ethos in the current Brazilian Constitution?

Ethos does not follow (not a consequence of) the text of the Constitution, but the text of the Constitution reveals the ethos. As Alexander Tsesis (2017, p. 85) claims, "Constitutional ethos is not, however, a textual creation. It refers, rather, to the principle of justice that the collective group, commonly referred to as 'the people', recognizes to have higher normative status than any contemporary majority". The principle of justice of the "people” is the reference to the constitutional ethos.

So, if one cannot find in Brazilian constitutional normative history an ethos, is it possible that the Constitution of 1988 reveals the Brazilian Constitutional Ethos?

It is the current Constitution that marks the transition of the country's democratic transition, which is still in progress, and which has allowed the emergence of the protection of the human being in the contemporary legal order of the country. Redemocratization called for the (re)construction and strengthening of democracy to overcome the authoritarian legacy and the construction of the possibilities of the future.

However, Brazil did not undergo a rupture from the dictatorial period to democracy, as above stated with was a transition that maintained old authoritarian laws - such as the Amnesty Law. In this matter, the Action against the Violation of a Constitutional Fundamental Right (ADPF) No. 153, the Federal Supreme Court (STF) considered the Brazilian amnesty, embodied in Law No. 6.683 /1979, compatible with constitutional provisions. This is a good example for the "authoritarian rubble" (FERNANDES, 1987, p. 9, our translation), above referenced. 
In the teachings of Chueiri and Câmara (2015, p. 260-261, our translation):

Discussing the Amnesty Law puts us face to face with the military dictatorship and the democratic transition, but, above all, with the constitutional and democratic significance of our Republic, which, for this very reason, cannot be silenced in the face of duty to investigate and prosecute cases of extreme violence that characterize crimes against humanity, even if this means, for example, the repeal of the Amnesty Law itself. The Fundamental Precept Failure Statement 153 (ADPF 153) (cf. Supreme Federal Court, s.a.) opened exactly this possibility of revising it (the Amnesty Law) and, through it, resuming the discussion about the dictatorship, the democratic transition and the responsibility of the Brazilian State in the face of the atrocities it promoted and sponsored.

Brazilian democratic consolidation still coexists, however, with authoritarian rubbish. Transitional justice, still incomplete in Brazil, represents the "transition from a political regime (in which there were serious violations of human rights) to another, which expects for peace and consolidation of democratic values.” (JUSTIÇA..., 2012, our translation).

As Paixão (2006, p. 6, our translation) teaches:

Traditions, political practices and mental attitudes are difficult to change. Although in a latent way, they remain guiding the imaginary of society, either by manifestations of pure irrationalism, or by the memory of a past that is suddenly idyllic, comforting, happy. In the Brazilian case, these traditions are marked by an authoritarian heritage.

To do so, this path implies (i) ascertaining the responsibilities of the perpetrators of barbarism, (ii) thus revealing the truth about past events, thereby opening the possibility of (iii) compensation to victims and (iv) reform and consolidate institutional practices and institutions ${ }^{15}$.

In this regard, the jurisprudence of the Inter-American Court claims for the invalidation of the self-amnesty laws ${ }^{16}$ - referenced by the Court as international crimes - and the interruption of authoritarian and dictatorial practices ${ }^{17}$, confirming the consolidation of the rule of law in the region and exhorting the popular access to participation and information. The Brazilian case is an example of this, since the “Access to Information Law” (a type of "public accountability law”) was mainly fostered by the judgment of the case Gomes Lundt et al. versus Brazil (Guerrilha do Araguaia), on 11/24/2010, in which the Brazilian amnesty law was considered invalid ${ }^{18}$.

15 See INTER-AMERICAN COURT OF HUMAN RIGHTS (1988). Although there is no invariable pattern, there is a minimal set of transitional justice identifying issues, as set in the ruling: (a) to take reasonable measures to prevent violations of human rights, $(b)$ provide mechanisms and tools for elucidation of situations of violence, $(c)$ have a legal apparatus that makes it possible to hold perpetrators accountable, and $(d)$ ensure compensation for victims through actions aimed at the material and symbolic repair.

16 The reference precedent is the case Barrios Altos vs. Peru. (INTER-AMERICAN COURT OF HUMAN RIGHTS, 2002).

17 Emblematic in this influx is the case Constitutional Court v. Peru that condemned the State for arbitrarily dismissing judges of the Peruvian Constitutional Court (INTER-AMERICAN COURT OF HUMAN RIGHTS, 2001).

18 In the words of the Court: "[...] the Court reiterates that 'amnesty provisions, the statute of limitation provisions, and the establishment of exclusions of responsibility that are intended to prevent the investigation and punishment of those 
In view of the provisions above, due to the incompleteness of the democratic transition (VENTURA; CETRA, 2012, p. 27-28), the ethos was not fully reflected in the interpretation of the rules of the current Constitution, with a view on rights, the common good, facing progressive and, sometimes, conservative moments. This is very important on the current days, when flirting with authoritarian tendencies again.

It is rather difficult to extract an ethos from the interpretation of the Constitution of 1988, because in Brazilian tradition, unlike the north American one, it seems that the Constitution is leading the way, not paving something that was already ready. According to Alexander Tsesis (2017, p. 158):

To remain relevant, constitutional principles must be informative to practical legal questions. The original maxim remains binding because it is predicated on human nature and the structure of representative government. But judicial, legislative and executive interpretation should not be stagnant. All three branches must be informed and responsive to current needs, the lessons of history, the developments of culture, and the will of the people. I am, therefore, proposing a system maintaining stability while providing the space needed for social change.

Not only the ruptures that occurred in the Brazilian legal and social fabric, but those that occur daily make it difficult to discover the constitutional ethos. As mentioned above, the process of constitutional mischaracterization promoted by the recent reforms, and now the rise of democratic populism is constantly testing the survivor of current Brazilian constitutional order.

Although the Brazilian Constitution contains textual rules on equality and respect to the dissent, concretely there are difficulties to full effectiveness. Firstly, it becomes difficult to establish what "the people" means, and what way people are the ethos reflected in the Constitution: it is a multiple society in which there is not only one voice, but a plural one. Moreover, the Constitution is the safeguard of plurality. Alexander Tsesis (2017, p. 78) states that "Divergent voices are welcome and inevitable in a society that respects free speech for the advancement of personal and common goods.”

Secondly, significant Constitutional reforms in the past years came from informal processes, that is, changes to the meaning of constitutional provisions by informal means. On the one hand, Brazilian constitutional practice would appear to have reserves with the idea of constitutional informal change, particularly because of the difficulty of controlling its constitutionality and because the Judiciary would gain significant power. On the other hand, however, this argument loses strength given that it is from the interpretative point of view that major constitutional reforms took place in the last years in Brazil.

responsible for serious violations to human rights such as torture, summary, extrajudicial, or arbitrary executions, and enforced disappearance are not admissible, all of which are prohibited for contravening irrevocable rights recognized by International Law of Human Rights.”' (INTER-AMERICAN COURT OF HUMAN RIGHTS, 2010, p. 64). 
An example to illustrate the argument is the social security reform, recently enacted in Brazil under the constitutional amendment number 103/2019. This amendment breaks the founding principle of the constitutional social order, which is solidarity to guide the actions of the State and society. The admission of such forms is proof of the lack of a pre-established ethos in the current constitutional text.

\section{IS AN ETHOS DECLARED IN THE PREAMBLE OF THE CURRENT BRAZILIAN CONSTITUTION?}

Alexander Tsesis highlights "the people" in the preamble to the United States Constitution as one of the most important passages to identify the constitutional ethos. The Preamble declares:

We the People of the United States, in Order to form a more perfect Union, establish Justice, insure domestic Tranquility, provide for the common defence, promote the general Welfare, and secure the Blessings of Liberty to ourselves and our Posterity, do ordain and establish this Constitution for the United States of America (UNITED STATES OF AMERICA, 1787).

Tsesis (2017, p. 27) states that

The Preamble's opening words, "We the People of the United States, in order to form a more perfect Union... establish this Constitution for the United States of America”, clearly indicate that the people - not the states nor any other unit of government - remain the deciding force of constitutional governance.

The people are the true sovereign and maintain the identity of the United States of America. The Preamble carries cultural importance, weight of authority, and is powerful constitutional rule to be considered next to the Constitution itself. As Professor Mark Tushnet (1999, p. 13) explains, “The Declaration and the Preamble provide the substantive criteria for identifying the people's vital interests.”

Now, from the Preamble of the Brazilian Constitution:

We, the representatives of the Brazilian People, convened in the National Constituent Assembly to institute a democratic state for the purpose of ensuring the exercise of social and individual rights, liberty, security, well-being, development, equality and justice as supreme values of a fraternal, pluralist and unprejudiced society, founded on social harmony and committed, in the internal and international orders, to the peaceful settlement of disputes, promulgate, under the protection of God, this CONSTITUTION OF THE FEDERATIVE REPUBLIC OF BRAZIL (BRASIL, 1988, our translation).

On the textual differences, it is possible to state that: (1) the "representatives of the Brazilian people” enacted the Constitution; (2) the protection of God was invoked. At no time the US Constitution does the same. 
But there are not only textual differences. The normative force of the Brazilian Preamble was denied by the Federal Supreme Court (ADI 2076), in Direct Action of Unconstitutionality (abstract control) involving the Social Liberal Party (PSL) vs. Legislative Assembly of the State of Acre. The obligatoriness of invoking the protection of God in the Preamble of the Constitution of the State of Acre (a State located in the North of Brazil) was discussed The Supreme Court ruled that the Preamble of the Constitution has no "normative force" and is not a central rule, and there is no obligation to invoke God. Considering the thesis of the legal irrelevance of the preamble in Brazilian law, there is no Brazilian constitutional ethos (declared in the Preamble) ${ }^{19}$.

In Brazilian Constitutionalism, the thesis of legal irrelevance of the preamble prevailed, being placed as a political statement, rather than a rule. This is the understanding and interpretation of the Judiciary branch. For part of the doctrine, based on Kelsenian knowledge, the preamble expresses political, moral and religious ideas having an ideological rather than judicial character. So, no ethos can derive from the absence of authority - nor legal or political - of such text.

\section{WOULD AN ETHOS COME FROM THE ETERNITY CLAUSES?}

The 1988 Constitution contains some petrified clauses ${ }^{20}$, which are permanently stable and impose material limitations to the power of reform (make amendments to) the Constitution. The Constitution has been amended more than a hundred times since 1988, but none of the times has changed, at least not formally, rules preserved by the eternity clauses.

Professor José Afonso da Silva (2007, p. 67, our translation) says that

[...] the fence reaches the pretension of modifying any element of the Federation, or of direct voting, or indirectly restricting religious freedom, or of communication or other right and individual guarantee; it is enough that the proposed amendment should go even remotely, tending (amendments tending, says the text) to its abolition.

Such clauses would serve to protect the spirit of the Constitution, for if they are not preserved, they would be faced with a new constitution, not an amendment. They are, therefore, clauses of intangibility and serve for the defense of democracy against the destructive effect of the opportunist majorities.

19 In this regard, the Supreme Federal Court (Supremo Tribunal Federal, STF) judgments are worth mentioning: "Preamble to the Constitution: it is not a central rule. Invocation of the protection of God: this is not a mandatory reproduction rule in the state Constitution, and has no normative force.” [BRASIL. Supremo Tribunal Federal. ADI 2.076. Requerente: Partido Social Liberal (PSL). Requerida: Assembleia Legislativa do Estado do Acre. Relator: Min. Carlos Velloso. Brasília, julgado em 15/08/2002, publicado em 08/08/2003 DJ. Available from: https://bit.ly/38pW7yk [Accessed: January 2020. Our translation].

20 Also called eternity clauses or hard-fought clauses. 
There is no consensus of interpretation and scope of such clauses in the Brazilian reality. The Supreme Federal Court (Supremo Tribunal Federal, STF) sometimes appropriates the meaning of the clauses, becoming an extreme activist, and expands and restricts their application in Constitutionality Control. The abstract character of the clauses is difficult to interpret and apply to the cases judged by the $\mathrm{STF}^{21}$.

However, it is also true in the concept of Alexander Tsesis (2017, p. 11), that the "Interpretation should liberally take into account the rights of all people, irrespective of their particular backgrounds or characteristics”, not using only mechanical models of interpretation. Although there is an interpretative response to the rights of the people, the "vast majority of constitutional controversies are likely to fall under the rubric construction” (TSESIS, 2017, p. 118). This also happens in the interpretation activity of the Supreme Federal Court of Brazil. Therefore, at this point, the Constitutional Law is similar.

The ethos of the Brazilian Constitution may be represented in the hard-fought clauses, as a framework that must be constructed interpretatively. Not only from the interpretative point of view, but also because the Supreme Court in Brazil has already ruled that constitutional amendments can be unconstitutional ${ }^{22}$. This power is justified as a mechanism to protect the constitution and its petrified agreements, but can be a way to diminish the power of Executive and Legislative branches can also be deemed.

In this sense, Daniel Sarmento and Cláudio Pereira de Souza Neto (2012, p. 402-405, our translation) warn:

[...] it is not salutary to attribute to anybody the prerogative of giving the last word on the meaning of the Constitution. The Constitution is definitely not what the Supreme Court says it is. In terms of constitutional interpretation, the Court, made up of human and fallible interpreters, can err, as can the Legislative and Executive branches. It is preferable to adopt a model that does not attribute to any institution - neither the Judiciary nor the Legislative the "right to make the last mistake", opening up the permanent possibility of reciprocal corrections in the field of constitutional hermeneutics, based on the idea dialogue, instead of

21 On this matter: "[...] it is currently stated that such clauses must be interpreted restrictively. This simplistic statement, instead of solving the problem, can aggravate it, since the detected trend acts in the sense not of a restrictive interpretation of the stone clauses, but of a restrictive interpretation of the principles they protect. This way, instead of allowing the strengthening of the constitutional principles contemplated in the 'guarantees of eternity', as intended by the constituent, effectively causes its weakening.” [BRASIL. Supremo Tribunal Federal. ADPF 33 MC. Arguente: Governador do Estado do Pará. Arguido: Instituto do Desenvolvimento Econômico-Social do Pará - IDESP. Relator: Min. Gilmar Mendes. Brasília, julgado em 29/10/2003, publicado em 06/08/2004 DJ. Available from: https://bit.ly/3bxsZaq [Accessed: February 2020. Our translation].

22 In an empirical study on the judicial control of amendments: "[...] jurisprudence of the current STF is very restrictive in relation to the declaration of unconstitutionality of ECs. As observed in the present work, ministers tend to demand specific criteria, established in jurisprudence, when, for example, accept the ad causam legitimacy of certain claimants in the context of this type of ADI, yet only once was a request for unconstitutionality fully upheld and only $17 \%$ of the proposed ADIs on the subject were terminated on the merits.” (ARRUDA, 2018, p. 79, our translation). 
the more traditional view, which grants the STF the last word in this area. [...] The decisions of the STF in constitutional matters are not susceptible to invalidation by political bodies. This, however, does not prevent a new law from being enacted, with content similar to that which was declared unconstitutional. This position can be derived from the constitutional text itself, which did not extend to the Legislative Power the binding effects of the decisions rendered by the STF in the control of constitutionality (art. 102, § 2, and art. 103-A, of the Constitution). If that happens, it is very likely that the new law will also be declared unconstitutional. But the result may be different. The STF can and should reflect on the additional arguments provided by Parliament or debated by public opinion to support the new normative act, and not ignore them, taking the new legislative measure as an affront to its authority. In the meantime, in addition to the possibility of altering the position of some ministers, there may also be a change in the composition of the Court, with repercussions on the outcome of the judgment.

In these past 30 years, the Judiciary has become, along with Congress, one fo the protagonist of this debate, if not the lead interpreter. This, as above stated, comes with many other problems that cannot be far more addressed in this paper ${ }^{23}$. But, as long as the ethos goes, it is not the Judiciary duty to state it, but to preserve it.

\section{CONCLUDING REMARKS}

There are undoubtedly points of contact between the North American constitutional construction of the ethos and the Brazilian constitutional tradition. The differences, however, remain, especially because of the history of ruptures of Brazilian constitutionalism.

In an attempt to find a constitutional ethos, Tsesis argues that the foundational standard is essential for maintaining pluralistic constitutionalism gains special interests. This has never been so true and adjusted to the Brazilian context. Returning to Alexander Tsesis (2017, p. 85), when he states that "the constitutional ethos is a principle that empowers individuals to flourish by pursuing their unique life quests while also maintaining coercive standards for government to advance policies likely to achieve collective goods.”

There was no time for the founding of a strengthened ethos in Brazilian constitutionalism so-far, which will be built over the decades by the minds of scholars. The Brazilian constitutional ethos, which has always faced friction and setbacks, will be formed in the sense of the common good, the rights of the people, the well-being, aiming at a plural society and with respect for the other.

A test of democracy and legitimacy is experienced in the current moment of Brazilian constitutionalism. The populist government is scratching deeply marks and the remaining question

23 For more, see: BARBOZA, Estefânia Maria; KOZICKI, Katya. O Judicial Review e o ativismo judicial da Suprema Corte americana na proteção de direitos fundamentais. Espaço Jurídico Journal of Law [EJJL], Joaçaba, v. 17, n. 3, p. 733-752, 2016. https://doi.org/10.18593/ejjl.v17i3.8750. 
is: will the construction and consolidation of the ethos prevail in a future constitutional horizon in Brazil or will come another rupture in Brazilian democratic constitutionalism tradition?

\section{REFERENCES}

ARRUDA, Ana Luiza Gajardoni de Mattos. O Supremo Tribunal Federal e o Controle Judicial de Emendas Constitucionais. 2018. Monografia (Extensão universitária) - Escola de Formação da Sociedade Brasileira de Direito Público (SBDP), São Paulo, 2018. Available from: https://bit.ly/3rteoCB [Accessed: January 2020].

BALEEIRO, Aliomar. Constituições Brasileiras. 3. ed. Brasília: Senado Federal, 2012. 2 v., 25 p. Available from: https://bit.ly/3sZ88CO [Accessed: February 2020].

BARBOSA, Leonardo Augusto de Andrade. História Constitucional Brasileira. Brasília: Edições Câmara, 2012.

BARBOZA, Estefânia Maria; KOZICKI, Katya. O Judicial Review e o ativismo judicial da Suprema Corte americana na proteção de direitos fundamentais. Espaço Jurídico Journal of Law [EJJL], Joaçaba, v. 17, n. 3, p. 733-752, 2016. https://doi.org/10.18593/ejjl.v17i3.8750.

BONAVIDES, Paulo; ANDRADE, Paes de. A Constituinte e a Constituição de 1988. In: BONAVIDES, Paulo; ANDRADE, Paes de. História Constitucional do Brasil. Brasília: Paz e Terra/Senado Federal, 1989.

BRANCO, Paulo Gustavo Gonet. Cláusulas pétreas. In: CAMPILONGO, Celso Fernandes et al. (Coord). Tomo Direito Administrativo e Constitucional. 1. ed. São Paulo: Pontifícia Universidade Católica de São Paulo (PUC-SP), 2017. Available from: https://bit.ly/3ryKNaM [Accessed: February 2020].

BRASIL. Constituição da República Federativa do Brasil - 1988. Diário Oficial da União, Brasília, DF, 5 out. 1988. Available from: https://bit.ly/2OhHwhz [Accessed: February 2020].

BRASIL. Supremo Tribunal Federal. ADI 2.076. Requerente: Partido Social Liberal (PSL). Requerida: Assembleia Legislativa do Estado do Acre. Relator: Min. Carlos Velloso. Brasília, julgado em 15/08/2002, publicado em 08/08/2003, DJ. Available from: https://bit.ly/3cfqpFi [Accessed: February 2020].

BRASIL. Supremo Tribunal Federal. ADPF 33 MC. Arguente: Governador do Estado do Pará. Arguido: Instituto do Desenvolvimento Econômico-Social do Pará - IDESP. Relator: Min. Gilmar 
Mendes. Brasília, julgado em 29/10/2003, publicado em 06/08/2004 DJ. Available from: https://bit.ly/2OwZ49s [Accessed: January 2020].

CARVALHO, José Murilo de. República, democracia e federalismo Brasil, 1870-1891. Varia hist., Belo Horizonte, v. 27, n. 45, p. 141-157, June 2011. Available from: https://bit.ly/3rsTmnC [Accessed: January 2020].

CHUEIRI, Vera Karam de; CAMARA, Heloísa Fernandes. (Des)ordem constitucional: engrenagens da máquina ditatorial no Brasil pós-64. Lua Nova, São Paulo, n. 95, p. 259-288, May/Aug. 2015. Available from: https://bit.ly/2Oe8zuf [Accessed: January 2020].

CODATO, Adriano Nervo. Uma história política da transição brasileira: da ditadura militar à democracia. Rev. Sociol. Polit., Curitiba, n. 25, p. 83-106, nov. 2005. Available from: https://bit.ly/3rvOj5E [Accessed: January 2020].

DERRIDA, Jacques. Declarations of independence. In: ROTTEMBERG, Elizabeth (Ed.). Negotiations: interventions and interviews, 1971-2001. Stanford: Stanford Univ. Press, 2002.

FERNANDES, Florestan. Adeus à Transição. Jornal do Brasil, Rio de Janeiro, p. 9, 19 out. 1987. Available from: https://bit.ly/2Oe91sr [Accessed: January 2020].

GASPARI, Elio. A ditadura envergonhada. São Paulo: Cia. das Letras, 2002.

GOLDEMBERG, José; DURHAM, Eunice R. A educação na reforma da Constituição. In:

D’ÁVILA, Luis Felipe Chaves (Org.). As constituições brasileiras: análise histórica e propostas de mudanças. São Paulo: Brasiliense, 1993.

GROSSI, Paolo. A história da propriedade e outros ensaios. Rio de Janeiro: Renovar, 2006.

HESPANHA, António Manuel. Panorama histórico da cultura jurídica europeia. Lisboa: Europa-América, 1997.

INTER-AMERICAN COURT OF HUMAN RIGHTS. Barrios Altos Case Chumbipuma Aguirre et al v Peru, 2002.

INTER-AMERICAN COURT OF HUMAN RIGHTS. Constitutional Court v Peru, 2001.

INTER-AMERICAN COURT OF HUMAN RIGHTS. Gomes et al. ('Guerrilha do Araguai') v Brazil, 2010.

INTER-AMERICAN COURT OF HUMAN RIGHTS. Velásquez Rodríguez v. Honduras, 1988.

JARDIM, Flávio Jaime de Moraes. A doutrina da living constitution segundo a ótica de David Strauss e o julgamento da reclamação n. 11.243 e da petição avulsa na extradição n. 1.085 pelo STF (caso Cesare Battisti). 2012. 162 f. Dissertação (Mestrado em Direito) - Instituto Brasiliense de Direito Público, Brasília, 2012.

JUSTIÇA DE TRANSIÇÃO. In: DICIONÁRIO de Direitos Humanos. 2012. Available from: https://bit.ly/3v5YVKP [Accessed: September 2012]. 
MACEDO, José Arthur Castillo de. Encruzilhadas do Federalismo. 2018. 148 f. Tese (Doutorado em Direito) - Universidade Federal do Paraná (UFPR), Curitiba, 2018. Available from:

https://bit.ly/3bqwgrV [Accessed: December 2019].

PAIXÃO, Cristiano. A Constituição subtraída. Constituição \& Democracia, Brasília, n. 1, p. 4-5, fev. 2006.

PIOVESAN, Flávia. 'Planos global, regional e local’. In: SOUZA NETO, Cláudio Pereira de; SARMENTO, Daniel (Ed.). Direitos Sociais: fundamentos, justicialização e direitos sociais em espécies. Rio de Janeiro: Lumen Juris, 2008.

PRADO JR., Caio. Evolução política do Brasil: Colônia e Império. 13. ed. São Paulo: Brasiliense, 1993.

SARMENTO, Daniel; PEREIRA NETO, Claudio de Souza. Direito constitucional: teoria, história e métodos de trabalho. Belo Horizonte: Fórum, 2012.

SILVA, José Afonso da. Curso de Direito Constitucional. 28. ed. São Paulo: Malheiros, 2007.

TSESIS, Alexander. Constitutional Ethos: Liberal Quality of the Common Good. 1. ed. New York: Oxford University Press, 2017.

TUSHNET, Mark. Taking the Constitution Away from Courts. Princeton: Princeton University Press, 1999.

UNITED STATES OF AMERICA. Constitution. 17 September 1787. Available from: https://bit.ly/3btVyWh [Accessed: January 2020].

VENTURA, Deisy; CETRA, Raísa Ortiz. O Brasil e o sistema interamericano de direitos humanos: de Maria da Pena à Belo Monte. In: Seminário Internacional 'Limites e Possibilidades da Justiça de Transição - Impunidade, Direitos e Democracia’, 2nd, 2012, Porto Alegre. Anais eletrônicos [...]. Porto Alegre: PUC/RS, 2012.

VENTURA, Zuenir. 1968: o ano que não terminou, a aventura de uma geração. Rio de Janeiro: Nova Fronteira, 1988.

VIANNA, Oliveira. O idealismo da Constituição. Rio de Janeiro: Ed. Terra do Sol, 1927. 